\title{
The Resolution Method of Aceh Conflict in The Perspective of Islam
}

\author{
Prof. Sukiman \\ Faculty of Ushuluddin, State Islamic University Of North Sumatra (Uinsu), Medan, Indonesia \\ The Centre For Islamic Development Management Studies (Isdev) \\ Pusat Pengajian Sains Kemasyarakatan, Universiti Sains Malaysia 1180 Minden, Pulau Pinang
}

\begin{abstract}
This paper aims to analyze the resolution of Aceh conflict from an Islamic perspective. Several decades Aceh has experienced conflicts continuously between the Indonesian governement and the people of Aceh. Aceh conflict arises because of the central government ignorance the wishes of the people of Aceh as an autonomous region who runs the Islamic Sharia (laws) as the basis of life of the country, nation and the society. In addition, the central government has exploited the very big earth resources for central development and very little shared for the development of Aceh. This condition uprises the people' rebellion for seperating from Republic of Indonesia. The rebellion is solved military style that causes the suffering for the people of Aceh till the devastating tsunami in 2004 that increased the misery of the people of Aceh. If the Aceh conflict is resolved by conventional method like in the West, which only emphasizes the importance of the material and worldly, the peace in Aceh will not be lasting and thus rises the new conflicts, because each party will demand their rights and will. The people of Aceh who have rooted implement Islamic Sharia should resolve this conflict in Islamic way, such as ishlah (peace), shura (discussion), understand the wisdom of the conflict, patience, resignation and implementing a kaffah Islamic teachings.
\end{abstract}

Keywords: Al Qur'an; Resolution Method; Conflict; Aceh

\section{INTRODUCTION}

Aceh province has been declared as an autonomy region to implement Islamic laws in Indonesia. As an Islamic region, the people of Aceh deservedly won the peace and prosperity in line with their ambitions to be Darussalam (welfare state). The prosperous Negeri Aceh once had been successful in the era of Sultan Iskandar Muda who practiced Islam as the basis of Aceh development. But when Aceh became part of the Republic of Indonesia, Aceh had less peaceful even to be a conflict area. Since the beginning of Indonesia independence, Aceh has conflicts with the central government because the government does not give the wish of Acehnese Muslims to implement Islamic laws in the central government. Even the central government discriminates against Aceh, so that they made rebellions with the goal of its struggle for its independence from Indonesia. The conflict in Aceh is very contrary to Islamic values because in many activities they cause many victims who died by killing, arson, damage the general facilities, violence and intimidation towards the people. The conflict 
causes misery and suffering for the people very badly even Aceh region has changed as war (Dar al-Harbi) area.

Many efforts made to resolve the Aceh conflict, but always failed. The failures are due to each party use different ways and the wishes of each party to take the interests of achieving the peace. Except the last peace that creates Memorandum of Understanding (MoU) in Helsinki Finland on August 15, 2005. However, this peace has been reached after the tsunami disaster, but the peace process itself used common peace methods and the role of Westerners who ignored the principles of peace based on Islamic methods. Therefore, this peace is still not in line with the meaning of the Islamic peace, as after the MoU, there have been intimidation, terror, murder, destruction though only on a small scale.

In the view of Islam, conflict has begun at the time of Adam AS since Qabil and Habil and then constantly followed by the human after them, including Muslims. This conflict can occur among individuals, households, communities and even nations. But Islam has a special method to resolve conflicts in various stages to achieve the peace. Those peace methods are tried to present in the Aceh conflict.

\section{REVIEW OF LITERATURE}

\subsection{The History of Aceh Conflict}

The history of the conflict in Aceh society began in the early independence of Indonesia between the Ulubalang group (aristocracy) who were less supportive of Islamic law got their support from the Dutch colonials on one side and those who want the enforcement of Islamic law on the other side. Both groups cause the dispute that eventually led to a civil war known as the War Cumbak. ${ }^{1}$ According to Al-Chaidar (1999: 113), this bloody incident did not dampen the spirit of the people of Aceh to defend the Republic of Indonesia. Even the spirit of the people of Aceh wass getting stronger against the struggles of this newly independent nation.

When Sukarno came to Aceh to ask for a huge participation help from the people of Aceh to save the Republic of Indonesia then all the people of Aceh were willing to defend

\footnotetext{
${ }^{1}$ According to Tengku M. Ali, the Cumbak incident arose from the dispute of the weapons seizure in Sigli between Persatuan Ulama Seluruh Aceh (PUSA) Ulama Association (PUSA) and some Oeleebalangs, but Indonesian Communist Party ex Digulis name Natar Zaenuddin involved in contacting PUSA persons and Oeleebalang, After having the information about the Japanese army who had to surrender their weapons, then Oeleebalangs occupied Sigli and although they did not remain silent to gather the people and Cumbak incident occurred because of a dispute to possess the weapons. (TM Ali, 1996: 3536).
} 
this Republic against Netherlands. The Aceh Mujahideen struggled throughout East Sumatera Front famous known as "Medan Area". Acehnese fighters were sent there to fight against the Dutch who wanted to go through the Medan Area to go to Aceh. Besides striving physically, Aceh also sent tens of thousands of tons of rice, thousands of cattle and buffaloes, thousands of bags of chips, either rice or egg fruit and a variety of other provisions to fight. Moreover, Aceh also provided ammunition, logistics and armament teams either for Medan Area Front or West Sumatera Front. Then help of the people of Aceh was willingly sold their gardens, fields, farms, ornaments like gold and silver to help the government to fill the country's finances. Thereafter Sukarno declared that Aceh is the finance capital of the Republic of Indonesia and from the people of Aceh Indonesia could be retaken (M. Nur El-Ibrahimy, 1999: 42).

Other aids requested by Sukarno to the people of Aceh were the Aceh merchants who belonged to Aceh District Merchant Affiliate organizations (GASIDA) to collect money to buy a plane. ${ }^{2}$ Finally, the Aceh merchants agreed to buy two aircrafts for RM480,000. However, after giving the money price of a plane to Soekarno by TM Ali and Resident Aceh Tengku Chik Daudsyah, but only one plane bought which named seulawah I. The plane was operated abroad on behalf of Indonesia Air Ways under commanding commodore Wiweko Supono. Meanwhile, another plane was never purchased and the money went somewhere disappeared (M. Nur El-Ibrahimy 1980: 45). With cancelling the other plane, but the money was given, then the Acehnese people felt betrayed by Soekarno whom considered not carry out the mandate of the people of Aceh.

In addition, when Sukarno visited Aceh, he sworn in the name of Allah to arrange the regional plan budget in accordance with Islamic Sharia. But the promise has never existed. On the contrary, the central government took an action that made the hearts of the people of Aceh hurt. The action was "Dissolving Negeri Aceh" ${ }^{3}$ and joined North Sumatera with the reasons: (1) Aceh did not have any specialists such as legal scholars, engineers, doctors, leaders or executors. (2) Aceh did not have sufficient financial resources to finance the

\footnotetext{
${ }^{2}$ Through the influence of Tengku Muhammad Daud Beureueh who at that time was the leader in Aceh, Langkat and Tanah Karo called the other merchants and the leaders of Aceh to discuss the problem about what Sukarno wished for. In a short time the merchants were able to collect large money and agreed to buy two planes, each of them costed \$ US 120,000 (M. Nur El-Ibrahimy, 1999: 44).

3. Aceh province is formed by the Deputy Prime Minister Syarifuddin Prawiranegara with the regulatory Deputy Prime Minister of the legal successor government regulation No. 8/Dec/WKPM / 1949, with a government regulation in lieu of law No. 51950 (M. Nur El-Ibrahimy, 1980: 53).
} 
province. (3) If Aceh was given independence how about other regions in Sumatra and Indonesia.

From the mistake of the central government of Aceh province that vanish the Aceh Province, this make the Acehnese people were hurt that created rebellion of Darul Islam / Islamic Army of Indonesia led by Muhammad Daud Beureueh ${ }^{4}$ by declaring Aceh as an Islamic state. The volatility is largely as a result of the inability of the central government to obtain a strong belief among certain regional political elites. Nevertheless, only the movements of Darul Islam and Islamic Army of Indonesia (DI / TII) flew the "flag of Islam" (Taufik Abdullah 2002: 446). It was the political situation in Aceh with the Darul Islam movement until the name changed to the State of Aceh $^{5}$ that later changed to the Islamic Republic of Aceh.

Darul Islam Aceh movement finally could be extinguished in October 1962 on an appeal by General A. Haris Nasution through Military Commander of Iskandar Muda I, Colonel Muhammad Yasin Muhammad Daud who held negotiations with Muhammad Daud Beureueh to resolve the Aceh conflict. In the negotiations, the central government promised to give full rights to implement "sharia" for the people of Aceh (Al-Chaidar 1999: 136). But eventually the central government succeeded in compromising efforts to end the conflict. Aceh is recognized as a special autonomous region, especially in religious matters, customs matters and education on the condition that autonomy is not incompatible with the Constitution. (Taufik Abdullah 2002: 448).

Next in the New Order of Indonesia led by President Soeharto in which Muhammad Daud Beureueh returned to Republic of Indonesia ${ }^{6}$ and agreed that "in Aceh it will be implemented the elements of Islam Shariah within the limits allowed by the laws and regulations of the country (M. Nur El-Ibrahimy 1986: 218).

The People of Aceh have not felt the peace and prosperity condition for long, it arose the separatist group Aceh Freedom (AM) as the result of the development policies of the New Order government which less support the implementation of Islamic Shariah in Aceh. It led

\footnotetext{
${ }^{4} \mathrm{He}$ is a former governor of Aceh Military, Langkat and Karo and former governor of First Aceh. He commited this armed movement/ rebel on 23 September 1953 at the same time the opening of the third National Sports Week in Medan (M. Nur El-Ibrahimy, 1980: 72).

${ }^{5}$ This tension arose after the Conference Office at Batee Krueng on 21 September 1955 and the Congress of Aceh People was held on 23 September 1955 who decided that the Aceh region that had become part of Islamic Indonesia into a state of Aceh.

${ }^{6}$ This incident occurred at approximately 1962, after negotiation between the Central Government and DI/TII especially regarding an agreement about the return of M. David Beureueh to Republic of Indonesia along with conditions to impose Islamic law in Aceh (Sufism, 2008: 223).
} 
the people of Aceh to be individualistic and materialistic. Moreover, after the discovery of gas field in Arun, the central government tried to exploit it. In a short time the area around the discovery of natural gas supply has been turned into a massive construction that spent huge financial toward the giant project. Four years later various industries established such as PT Arun LNG, PT. Pupuk Iskandar Muda PT. Kertas Kraft Aceh and a number of other industries (Al-Chaidar 1999: 140). The presence of Aceh multi industry has brought great changes to the socio-cultural of Islamic Aceh which becomes a region that materialistic, individualistic and low moral value due to the entrance of overseas citizens from different religions and cultures. The other side is that the people of Aceh in that area sold their lands as displaced by the construction industry. They moved to the outskirts of the city which in turn creates the difference of lifestyles between the rich and the poor so that it weakened the Islamic brotherhood that has been developed. ${ }^{7}$

Seeing the condition of the culture, politics and economy which are built by the New Order government does not benefit the Muslims of $\mathrm{Aceh}^{8}$, and then the arise of Free Aceh Movement (GAM) declared by Hasan Tiro on December 4, 1976 in Mount Haliman Pidie added widespread conflict that leads to religious teachings. Free Aceh Movement (GAM) of Hasan Tiro version which is wrapped neatly in the frame of Islam apparently has extended the ideas that are contrary to Islam and the customs of Aceh (Al-Chaidar, 1999: 1410). Even according to Abu Jihad (2002: 58), the pattern of GAM's struggle now can be said to be the attitude of tyranny. The tyranny action was scaring people, creating dissension among the people, even if necessary killing is a justification for waging the struggle. According to him, there are three patterns of Hasan Tiro, GAM's struggle: First, the majority of GAM combatants are civilians. Second, it is not an obligation to worship God ${ }^{9}$. Third is doing a propaganda action. The above GAM's struggle pattern is contrary to the values of Islam because education and knowledge are greatly appreciated in a struggle. Likewise, obedience to Allah by practicing worships is the main key in implementing Jihad fi Sabil Allah. Because the people who practice the good deeds mean they have helped religion and those who help

\footnotetext{
${ }^{7}$ Because Aceh has been betrayed by the Government of New Order, and added the people of Aceh were shocked seeing their region looted by the Central Government. So there was a same perception of the people of Aceh to the Government of New Order with its predecessor the Old Order government, that is the governments were equally deceptive (Al-Chaidar, 1999: 141).

8 Because Aceh has been betrayed by the Government of New Order, and added the people of Aceh were shocked seeing their region looted by the Central Government. So there was a same perception of the people of Aceh to the Government of New Order with its predecessor the Old Order government, that is the governments were equally deceptive (Al-Chaidar, 1999: 141).

${ }^{9}$ Worship is not a criterion, so that the members are not required to be religious, even if it piracy, drugs, if they are loyal to the supreme leader it is more preferred (Abu Jihad, 2000: 66).
} 
religion is surely to be helped by Allah. Moreover, doing evil deeds in the struggle to uphold Islam, is contrary to the essence of Jihad fi Sabil Allah. Based on such situation, then arise another similar movement of Darul Islam called Islamic Republic of Aceh (RIA), by using the paradigm of migration and jihad as an extension of the struggle of Darul Islam, which set to take the path of liberation and migration to declare again the Islamic Republic of Aceh independent from Indonesia (Abu jihad 2000: 135). That appears conflicts in Aceh. On one side from the military government of Indonesia and the other is from GAM who creates conflict continuously that claimed many victims and creates insecurity in Aceh. And the central government implements Aceh as a Military Operations Area (DOM) for 10 years (1989-1999). According to the National Information Agency (LIN) that: "for about 28 years, since the Free Aceh Movement declared by Hasan Tiro in Pidie, Aceh people cannot build their future. Feeling safe in Aceh land becomes very expensive, while suffering continues as GAM demands to secede from the Republic of Indonesia (A. Kadir Souyb 2004: 24). During the period of DOM in Aceh it claimed around 3800 to 5000 lives. According to the AlChaidar (1999: 112-148) there were 51 violence done by the military, 21 kinds of bitter story of the Muslims Aceh ${ }^{10}$ as well as violence against women ${ }^{11}$, all of which are rows of suffering and misery of the people of Aceh. Such condition that made the people of Aceh grudge to security army and the central government that almost all Aceh people participate supporting the Free Aceh Movement.

Even in the Reformation Era which began in May 1998. During the power of President Baharuddin Jusuf Habibie, he released one of the provinces, East Timor via a poll that cause it an independent state out of the Republic of Indonesia. That matter affects the reemergence the Free Aceh Movement (GAM) demands a referendum (poll of Acehnese people for independence or to remain within the state of Indonesia). The desire was still dammed by the leadership of Habibie to offer their special autonomy. On January 8, 1999, Aceh society delegation led by Governor of Aceh, Syamsuddin Mahmud met President Habibie by suing the society demand as follows. First, the people of Aceh demand for law enforcement on violations of Human Rights (HAM) by soldiers during the implementation of the Military Operation Area (DOM) in Aceh. Second, the people of Aceh asked President

\footnotetext{
${ }^{10}$ Among them are: covering the genital parts while praying, kidnapped from the mosque, tortured, kidnapped them killed, $d a i$ are tortured for 35 days, beaten, kidnapped looted and beheaded, shot and thrown into the ditch, terror, buried for 3 days, put in a sack, buried alive, cutthroats, sliced, three nights sleep with dead body, knocked out teeth (Al-Chaidar, 1999: 150180).

${ }^{11}$ Acehnese women were raped by three soldiers, rapes pregnant women, the pregnant girl gave birth to the rapist's child, raped while standing up, raped, electrocuted and beaten, undressed, husbands were kidnapped and the wives were raped, paraded naked and shot, raped in front of her son (Al-Chaidar, 1999: 181-190).
}

DOI: 10.9790/0837-2204067692 $\quad$ www.iosrjournals.org $\quad 81 \mid$ Page


Habibie to give amnesty and forgiveness to the Acehnese party and political criminal actors of Aceh. Third, the people of Aceh asked the President and the Parliament to formulate an Act to support Aceh's status as a Special area. Fourth, in terms of regional autonomy, the people of Aceh demand that the government of Aceh gain flexibility in managing the assets of the area without excessive interference from the central government. Fifth, the Law on the balance financially the center and a new area, the people of Aceh demand $80 \%$ of the natural wealth contained in Aceh (A. Kadir Souyb 2004: 51)

The government of Habibie at that time could not meet the demands of the people of Aceh quickly and thoroughly. Once again he repeated the violence during the DOM that made the increasing people's anger against the central government. AS the result the people of Aceh support the Free Aceh Movement (GAM) which makes the atmosphere of development in Aceh become worse.

The government of Indonesia led by President Abdul Rahman Wahid after Habibie gave a great opportunity to achieve the peace between the GAM and the Republic of Indonesia, which produces Geneva Switzerland Act $^{12}$ called mutual understanding between the humanitarian pause for Aceh. However, this agreement did not last long until mid-2001. The central government parties continue to offer autonomy. The two sides held an informal dialogue involving all elements of Acehnese society, including GAM. But during the seven months from July until February 2002 the dialogue deadlocked because of the difficulties in the field due to the increased resistance weapons (A. Kadir Souyb 2004: 53).

President Abdul Rahman Wahid once again hurt the people of Aceh, because of his promise to hold a referendum, ${ }^{13}$ but the options offered there is no "independence". Thus, the people of Aceh reject the offer. At the same time the People's Consultative Assembly (MPR) held hearing public referendum (MPR) which aims to contribute the achievement of the independence of Aceh. The situation was getting precarious and even Trikhotomi of conflict $^{14}$ happened between Republic of Indonesia and the civil society of GAM.

\footnotetext{
${ }^{12}$ The Geneva document, according to the Nanggroe Darussalam Governor Abdullah Puteh, the agreement must be made "once and for all and win the sacred mission of peace, for the sake of the development and the welfare of the people toward the new Aceh which is prosperous equitable and dignified (A Natural_Sciences M. (ed), $2003: 13$ ).

${ }^{13}$ President Abdul Rahman Wahid said he agreed that the referendum was conducted in Aceh but he assured the people of Aceh agreed to remain as the part of the Republic of Indonesia, as Aceh is not out of the republic. The Referendum offered by Abdurrahman was the special autonomy, total autonomy and the finance balance between the central and the local. $(\mathrm{H}$. Prabudi Said, 2006: 148)

${ }^{14}$ Conflict Trikhotomi is First: Republic of Indonesia, bureaucrats and soldiers who refused the repeal of the DOM, refused the judicial Human Rights, reconciliation without being accompanied by The Truth Commission, doing a dialogue without participating the third-party finishing the solution through military force, Islam, Special autonomy. Second. Gerakan Aceh Merdeka (GAM), Angkatan Gerakan Aceh Merdeka (AGAM) and bureaucrats, want the independence, dialogue role (guerilla), together with the people, internationalization, (third party), support the referendum, support the human rights and respect the help from abroad. Third: civil society, students Non Government Organization (NGO), reformer, families of 
Similarly, in the time of President Megawati Sukarnoputri ${ }^{15}$ after Abdul Rahman Wahid became president, GAM increasingly performed the resistance and revenge to the cuak (people who help National Indonesian Army (TNI) on the period of DOM. The situation is getting excessive with more of the violence, bombings, damage, burning schools. With a frightening situation and the victims became more crowded, the central government affected the "Darurat Militer" (Emergency Situation) in Aceh on May 19, 2003 through Presidential Decree No. 28/2003. The situation became uncertain, so that Aceh region became a war area (Dar al-Harb) (M.Said 1986: 160).

\subsection{Conflict Viewed From Islamic Perspective}

Conflict as a crisis in human life is something that is common happens. Conflicts can occur at the individual level, family, in society and among nations, states. According to Muhammad Shukri Salleh (1998: 2), the first conflict in human life occurred in paradise between Adam and his wife Eve with Satan. In this conflict involves questions about the use of khuld fruit which is forbidden by Allah. Adam AS and his wife Eve were defeated because they did not obey the commandments of Allah and the devil as the winner. The next conflict was between Qabil and Habil for owning a womaen that made Allah tests them to give sacrifice with the property, this conflict then ended with the murder of Habil.

According to Harun Yahya (1999: 10-45), the Messengers of Allah found conflict with their people. The prophet Noah, for example had a conflict with his people as they obstinately refused to Allah and the teachings of Prophet Noah [Surah al-Momineen (23): 26]. ${ }^{16}$ Similarly, the Prophet Luth had a conflict with his people as they perform acts of sodomy behavior [Surah Al-Qamar (54): 33]. ${ }^{17}$

Prophet Ibahim also had a conflict with his people as they worship idols and renounced the doctrine of Allah. Next Prophet Hud had a conflict with the Ad people who hated him and denied the truth of Allah's teachings [Surah al-Haqqah (69): 4]. ${ }^{18}$ Prophet Saleh had a conflict with Thamud people who hated him [Surah Hud (11): 62]. ${ }^{19}$ Similarly

violence victims and people who want DOM be revoked, move inorganic troops, uphold democracy, referendum, dialogue, cease-fire, refused the emergency, military civil, refuse all the instructions of President and ignore the Special autonomy Law (J. Antoine (ed), 2005: 34).

${ }^{15}$ She is the vice president for Abdul Rahman Wahid, but Gus Dur made a mistake of wisdom, until he was discharged by the Special Session of the People;s Consultative Assembly (MPR), in July 21, 2001 and appointed Hamzah Haz in July 26, 2001 for her deputy Prabudi Said (2006: 153).

${ }^{16}$ Meaning: "Noah said, Lord, help me because they deny me" [Surah al-Momineen [26): 26].

${ }^{17}$ Meaning: "The people of Luth deny the warnings" [Surah Al-Qamar (54): 33]

18 Meaning: "Thamud people and 'Ad people denied the Day of Resurrection" [Surah al-Haqqah (69): 4

${ }^{19}$ Meaning: "And they said O Shaleh! You have been our hope before this place. Do you forbid us to worship God for worship of our fathers? 'We are in doubt about what you call us and doubt." [Surah Hud (11): 62].

DOI: 10.9790/0837-2204067692 $\quad$ www.iosrjournals.org $83 \mid$ Page


Prophet Moses a.s. had a conflict with Pharaoh, the cruel ruler and always wanted to kill Moses, who still fought to defend Allah's teachings bitterly, that made Prophet Moses is classified in the group of $u l u l a z m i .{ }^{20}$ Saba people also had a conflict with their Prophet, they worshiped the sun before they followed Solomon.

The conflict between Prophet Muhammad PBUH with Quraish is the saddest one. It had been one year and five months the Prophet Muhammad spread Islam in Makkah, the Quraish often took the fight to him and made him hijrah to move to Tayib and then to Yathrib. According to Abd. Hamid and By Arifin (1970:189) this hijrah was done due to the critical condition in Makkah for the messenger and Muslims where every second they were in danger. The Quraish people met Abu Jahl and ordered him to seek and kill the prophet and his tribe, so at that time hijrah had to be done. The fight of Quraish continued, so the Prophet and the Muslims fought to uphold the teachings of Islam, then the conflict could not be avoided and there were some battles like Badr $^{21}$ and Uhud ${ }^{22}$ and Handaq. ${ }^{23}$

In view of al-Qur'an there are various heart characters who always fight the truth which can also create a potential conflict. Among these are the sick heart (fi qulubihim maradhun) [Surah al-Baqarah (2): 100] who have prejudice, suuzhan to others. There is a heart that was locked from the truth [Surah al-Baqarah (2): 8], there are also very hard heart as a rock (qassat qulubuhum fa hua kal Hijarah) [Surah al-Baqarah (2): 74], there is also found the heart closed from the kindness ('ama al-qulub) [Surah al-Baqarah (2): 88], some rude heart (ghalizh al-qalb) [Surah al-Imran 159]. This verse revealed in the battle of Uhud, where some Muslim soldiers disobey the prophet because they were affected the desire to take the spoils when the Quraish army were lose and this affair is an example of the conflict between the prophet and his army whose hearts are hard to take from the defeat. According to Ash Shabuny (1981: 240), the characteristic of a hard heart is speaking loudly, there is wickness in his heart and easy to leave the jamaah and tend to egoistic.

The conflict also can be created from evil thoughts because the mind that he has is not the mind of bearing (aql al-mustafad), or a mind that has correct reasoning (aql al-

\footnotetext{
${ }^{20}$ The prophets of lul Azmi are the prophets who struggle very hard and full of various challenges to defend the teachings of God. The prophets of lul Azmi are Muhammad, Ibrahim, Moses, Jesus and Noah

${ }^{21}$ This war occurred in Badar on the valley of al-Rish in March 13624 AD, with the involvement of Muslim troops and 113 people from the Quraish with total of 100 people. This war was won by the Muslims so as to strengthen the leadership of the Prophet PBUH (K. Ali, 2000: 30-31).

${ }^{22}$ This war happened in Uhud wadi Qamar (small well) on 21 March 625 AD involving a total of 3000 kafir and 1000 Muslims, but 300 people who defected. Uhud war could be won at first but because the men did not obey the messenger that made them finally suffered the defeat (K. Ali, 2000: 53).

${ }^{23}$ This war occurred in $627 \mathrm{AD}$, which involved 10,000 people of Quraisy kafir and 3,000 Muslims. The war is called Handaq because Madinah was protected from the threat of the Meccan kafir by digging the soil and rocks as a defense. This war was won gloriously by the Prophet Ali K. (2000: 58). 
mutakhayaal) but that thought has just filled with bil afal which its potential still can be used to perform evil deeds to others. When such thought is not educated on the values of Ilahiyah then it tends to be an evil thought that is always ready to have conflict with the truth.

Moreover, if there is a mazmumah passion in someone's soul which is supported by the heart and locked out of truth and useless thought supported by the satan whispers ${ }^{24}$ then the potential conflict is compete inside the person. Satan according to Ibn Saud (1993: 50), is a bad behavior creature that wish humans can be deflected from the straight way to the wrong way and be wrong person. Therefore, satan must be avoided because it is the real enemy [Surah Az Zuhruf (43): 62). Satan also invited the faithful man to be poor and ask human to do the crime (Surah Al-Baqarah (2): 268). Satan's disturbance is very powerful if those who already have heart disease, wicked mind and lust anger are very easy for them to have conflict that can bring misfortune and suffering.

If it is linked to the Aceh conflict which is rooted from the potentials mentioned above, added with internal potential of the people of Aceh that according to Anthony Reid that the people of Aceh always have conflict and violence. Likewise R.A. Kem, identifies Aceh and its people to madness (Aceh Moorden) so that with the madness they dared to fight against the Dutch on war with no weapons. Paul Vant Veer says that the people of Aceh are heroic. A. Muchsin 2007: 211). With such spirit the fanaticism of the people of Aceh are still smoldering, whenever they are betrayed and mistreated until they continue to fight in various ways.

Besides the internal causes, the Aceh conflict is due to external causes. According to Arifianto S. (2004: 86) the causes are: First, the society's stacked restless and dissatisfaction over their socio-economic, legal and political condition. second, the people's aspirations are blocked in the development of politics or there is a gap among economic development, politics and law. Third, the symptoms of poverty and the sharp inequality in development of economics, politics and law. fourth, the emergence of the phenomenon of wider corruption practices, partnerships and kinship. Fifth, there is an imbalance distribution of economy assets which only arrived by a small group in the society.

For decades the Aceh conflict has claimed many victims, property and the suffering of the people and can undermine the foundations of socio-economic and even cultural customs of the people of Aceh. From both disputing parties there have made some reconciliation

\footnotetext{
${ }^{24}$ The meaning of satan is derived from syatana or syata based syatahun which means becoming far away from the real world. If the word syata, it means burning or flaming, because passions or exaggerated emotions (Ibn Sulaiman, 1993: 44). 
(ishlah), especially the central government have tried to give special autonomy through legislation No: 18 in 2001 by giving the name of Province of Nanggroe Aceh Darussalam. Then it affects the Presidential Instruction No. 1 year 2002 about the improvement of comprehensive steps to accelerate the settlement of the Aceh problem. However, these efforts have not produced results yet even Aceh is getting more volatile. The efforts to avoid the bloodshed that has always highlighted by the international community have been tried with the Cessation of Hostilities Framework Agreement Between Government of the Republic of Indonesia And the Free Acheh Movement (GAM) that was signed on December 9, 2002 in Geneva, Switzerland. However, the deal was finally foundered because each party understand the meaning of peace differently until the results are without any trace (LIN 2003).

Aceh conflict was on peak with the devastating tsunami disaster that claimed hundreds of thousands people in Aceh and undermine the development of Aceh and it seems to make sense that Allah has taken over the peace in Aceh. The situation made everyone think and realize how bad the life of Aceh people that has never lived in peaceful and they suffere. Then the both sides made peace, in August 15, 2005 through Memorandum of Understanding (MoU) in Helsinki, Finland. However, this MoU was initiated by Martii Ahtisaari's role as the third party from Crisis Management Initial (CMI), which acts as a mediator to organize the peace in Aceh. The memorandum of understanding has also been supported by the community of nations such as the United Nations, European Union, United States and Japan (Abdul Jawad, 2007: 1).

From the Aceh peace activities, it can be seen clearly that they followed the role of Westerners who prevail peace that only concern the current peace and the interests of the world alone, without involving the role of Islam in it. ${ }^{25}$ Even if the Aceh peace has been achieved, but it is an apparent peace not the eternal peace which is based on Islam. According to Chief of Army Commander of Iskandar Muda Aceh, Major General Soenarko, said that the peace in Aceh still apparent because until now there are still many violence cases, the threats that make people afraid and insecure. According to him, the facts on the field prove that the security situation in Aceh after the MoU was still stained a various actions that could injure the spirit of peace and tranquility influence on public life. In one hand people feel the atmosphere of secure, peace. But on the other hand the people are also faced with a situation

${ }^{25}$ Yet according to Taha Hussein (1973: 33), says that Islam is a religion of enjoining the good deeds, forbidding evil deeds, pointing to the good and avoiding all the bad things. Islam requires the human affairs in a fair and set fairly and clean of various atrocities. 
of intimidation, kidnapping, coercion, extortion practices. ${ }^{26}$ The crime and intimidation toward the people which committed by certain parties that may not agree with the peace and a constant desire to create Aceh will have more conflicts so that ther will appear a new desire for independence for Aceh. According to Yuli Hartono (2004: 138), probably there is a hardliner who wants Aceh remains murky and reserved the conflict atmosphere. This group committed terror, violence, intimidation which deliberately created in order to their needs.

\section{DISCUSSION}

There are many things can be done and designed based on the conflict which has been happened for many years for people especially children and women in Aceh:

\section{a. Understanding the Lessons and the Goodness of Conflict}

As mentioned above that the conflict persists along with human life. However, this conflict should be understood as something that comes from Allah and it can be as a disaster and a temptation, especially to the believers [Surah al-Ankabut (29): 2], although no human being is willing to meet any disaster. In the view of al-Qur'an that the disaster is showing the power of Allah and the weakness of man that Allah has recorded it in Luh Mahfuz [Surah alHadid (57): 22] as part of his fate. The calamities do not mean that Allah is not unjust to His creatures, but Allah had a different iradah behind the disaster. The calamities are as tests from Allah so that the man passes into the muttaqin. Or this can be as elimination of their sins, or as Allah's way to increase the man's degree. It may be also a disaster as a means to educate the patience, calmness and resignation to Allah or the calamities are Allah's way to finalize the man's mind and behavior and perhaps also as Allah's way to humiliate and condemn the people who always refuse His orders (Muhmmad Shukri Salleh 1998: 4-5). Other Lessons to be learned from this conflict are ibrah dan mauizah ${ }^{27}$ they are lessons to be taken from various conflicts. The lesson is a new awareness that the conflict can only be selfdefeating and broad society that ends to the destruction and havoc. Such activity is a sin because it is contrary to Allah's command [Surah al-Araf (7): 33]. People who disobey Allah's order will get the punishment in this world and in the Hereafter they will go to hell. The next awareness is to understand themselves as khalifah and the servant of Allah, as khalifah they must have faith, science and charity so that they can be leaders who take care of

\footnotetext{
${ }^{26}$ Commander Military of Iskandar Muda Major General Soenarko (2008: 7) Serambi Indonesia, No. 6.9907 October 2008.

${ }^{27}$ Ibrah is a psychological condition that conveys the essence of a man who witnessed or faced with logic that causes the heart to admit it. Then mauizahialah is gentle advice received by the heart by explaining the reward or the threat (Ahmad Tafsir, 1991: 145). 
people and nature. As a servant of Allah, he must be down to earth, and surrender to Allah and to His commandments (Ibn Manzur, 1968: 259).

\section{b. Eliminating Mazmumah}

As stated above that mazmumah is a flaw nature. This nature can exist in a person whenever his passion is still in the stage of his anger that never regret of wrongdoing. Moreover, this kind of person keeps a serious heart disease that there is evil in his life and disobeys Allah. In the event of Aceh conflict it is seen as crime, contradiction, murder and destruction which are the characteristic of mazmumah. ${ }^{28}$ In tasawuf approach the way to get rid of this mazmumah are in three ways, namely takhalli, tahalli dan tajalli. Takhalli is an effort to empty ourselves from the mazmumah nature like kibir, riya, suuzdan, syumah, ghibah, hasad that can create a variety of crimes and inflame the conflict.

The effort to free ourself begins with taubat (repentance). Taubat is being regretful for the sins committed by not repeating them again (taubat nasuha), because according to the Sufis, the sins make people far from Allah S.W.T. So taubat does not only vanish the sin, but it is more than that, taubat as a prerequisite in order to be closer to Allah. According to Ibrahim Basuni (1969: 119), taubat can be distinguished into three categories, first, taubat by abandoning all evil deeds and do good deeds continually. Second, taubat is getting out of crime and into goodness for fear of Allah's anger and the third, taubat is ongoing repentance although never do any sins. The last taubat is called'alad dawwam taubator eternal repentance. According to Imam al-Qusyairiy (1959: 139) who explains that taubat can be considered valid if it meets three conditions: First, being regretful for the evil deeds he committed. Second, leaving the evil deeds. Third, being determined not to repeat the cursed act.

Tahalli is an attempt to fill or decorate themselves by making familiar with the practice of behavior, moral, and mahmudah. At this level someone is trying to make each of his work has always run well on the religion rules either it is external obligations such as prayer, fasting, zakat and hajj or internal obligations such as faith, obedience and love to Allah. Then tajalli, is a nur ghaib as an effort that has been emptied mazmumah. The result is an expression of deep love to Allah which is in itself a sense of longing for Allah has blossomed in that way. In fact, according to Mustafa Zahri (nd: 74), this level has already

\footnotetext{
${ }^{28}$ According to the record of Government of Aceh until the end of the May 1999 ten years imposed of Military Operational; Area (DOM) in Aceh claimed 8344 people, 1002 people died, 875 people missing, 1,465 women became widows, 4,670 children became orphaned, 34 women were raped, 298 people became disability (Sugeng Satrya Dharma, 2007: 86). 
acquired the essential spiritual happiness that has been able to absorb himself in the will of Allah is the most important act. If this way is taken by each individual of the people of Aceh and the central government who are in conflict, then peace will exist by itself without following the wishes of the people who are not necessarily sincere in helping the peace in Aceh

\section{c. Facing the Conflict with Moral}

Morals are the fruits of faith [Surah Ibrahim (14): 24-25] because the strong faith will produce a stronger prayer, and in the end it makes the sweet fruit and can be enjoyed by humans, animals and the environment. The essence of morality is doing good deeds which the source is from Islamic teachings. if someone committed a crime or an evil deed either to humans or to the environment it is a mufsid attitude which is deemed as immoral. According to Muhammad Quraish Shihab (1996: 255), the human tendency to goodness is proven from the equality of concepts of main moral in every civilization and age. If there is any difference, it lies on the form, implementation, and imperfect understanding toward the moral concept which is called ma'ruf in al-Qur'an. There is no civilization that considers good for lies, deceit or arrogance. And no man judges doing good deed to his parents is a bad deed.

\section{d. Hold Mesyuarah and Muzakarah}

According to M. Quraish Shihab (1996: 469), mesyuarah word is taken from the word sywr which means removing honey from a beehive. This meaning then evolved to include everything that can be removed including opinions. Mesyuarah can also mean to state or to ask something. According to him, honey is not only sweet but also is a medicine to cure many diseases, health resources and energy. Honey is produced by bees, if so anyone who performs mesyuarah he must be like a bee that is a very disciplined creature, its cooperation is amazing, the food is the from the flowers and the result is honey. Bees never damage, they do not bother unless are disturbed even bee stings are also as medicine. It is just like that the meaning of mesyuarah that must be done to overcome the crisis. Mesyuarah is done by producing honey that can be medicine and energy to achieve the peace. With syura or muzakarah many conflicts can be resolved with an opportunity to negotiate, discuss, eliminate prejudice, correct the error and find a point of understanding the truth (Muhammad Syukri Salleh, 1998: 10). 
Allah's says in Surah Ali Imran verse $159^{29}$ explained by M. Quraish Shihab (1996: 473-475), Allah commanded some attitudes relate to mesyuarah. First, being gentle for the participants who do mesyuarah and should avoid harsh speech and stubbornness, otherwise mesyuarah participants will walk out. Secondly, forgiving ( $f a^{\prime} f u$ anhum) and turning a new page, it means that the mesyuarah participants prepared mentally to always be ready to forgive the past mistake by removing being hurt in the past. Moreover, being forgiven is based on patience and trust so that each party is aware of the past mistakes. The mistake of the Central Government to the people of Aceh should be forgiven and in the same time the people of Aceh should also be able to forgive back.

The attitude of forgiveness given by the people of Aceh should be followed up so that the central government will not repeat the mistakes and provides the development services for Aceh better and dignified. Third, each mesyuarah participant begged maghfirah, Allah's forgiveness for the past mistakes so that the relationship with God becomes harmonious. If the three conditions mentioned above, the activity of mesyuarah will run well to get "honey". Moreover mesyuarah participants are the chosen ones and have admirable qualities from each parties who led the mission for the benefit of the Islamic people of Aceh.

\section{e. Return to Allah and the Messenger}

Mesyuarah can be deadlocked because each party claimed that they are the most righteous and victorious. In such situation, the search to find the truth is only referring to Allah S.W.T and His Messenger. Allah says in Surah Al-Nisa (4): 59:

O you who have believed, obey Allah and obey the Messenger and those in authority among you. And if you disagree over anything, refer it to Allah and the Messenger, if you should believe in Allah and the Last Day. That is the best [way] and best in result. [Surah Al-Nisa (4): 59].

Aceh conflict resolution which is often deadlocked, each party shall return to the teachings of Allah's spirit by referring to al-Qur'an and Sunnah, because the two are as very comprehensive sources of Islamic teachings. Moreover, Ahl Al-Syura ${ }^{30}$ involve the governments, community leaders and ulamas of Aceh whose commitments are very convincing. Therefore, the role of ulamas are very dominant in order to resolve the conflict in

\footnotetext{
${ }^{29}$ Meaning: "And by the Mercy of Allah that thou humble towards them. Had you been rough and hard-hearted, they would have dispersed from around you. So forgive them and ask forgiveness for them and ask mesyuarah for them in certain affairs. Then when thou hast taken a decision put thy trust in Allah. Indeed, Allah loves those who put their trust in Him [Al Imran (3): 159].

30 Ahl Al-Shura are leaders who can be asked for consideration and recommendation to others, there is another term used as Ahl Al-Hal wa Al- 'Aqd that is someone who has of influence in the community. But there is also mentioned as Ahl Al-Ijtihad that is the technocrats in various skills and knowledge (M. Quraish Shihab, 1996: 481).
}

DOI: 10.9790/0837-2204067692 $\quad$ www.iosrjournals.org $\quad 90 \mid$ Page


Aceh, because ulamas know exactly about Islamic law imposed in Aceh as the root of the conflict. According to Walid Warul (2006: 118-119), the Aceh mission in the history the struggle in the past and efforts to restore the present dignity basically lies in Islamic law. Islamic law for the people of Aceh is not only a symbol of struggle and politics, but it is the ultimate goal of the struggle and now the people of Aceh are back to their Islamic identity.

\section{f. Do not Revenge}

Conflicts exist over dissatisfaction with the everyday life matters, so resistance, violence and injustice can happen again on the party who made their hearts hurt. When the parties who are not satisfied have to take revenge to the case, then the conflict will continue and be long. But if there is no revenge on the matter, the conflict could be lost. Moreover the disgruntled persons exhibits mahmudah attitudes in the form of cautious, prudent and calm on the case. Moreover, if the conflict is stocked the issues of bad news brought by other groups who are not happy with the peace, the conflict are widespread and can escalate into war.

\section{CONCLUSION}

From the above description, it can be drawn several conclusions: First, the Aceh conflict occurred due to a mistake in the past committed by the central government in the form of promises to grant the autonomy to run the Islamic Sharia. But the promise was always eliminated even the role of the people of Aceh for Indonesian republic is put aside. Besides that Aceh's earth resources are dredged for the center development and give less attention to the development of Aceh. Second, the center government always imposes violence and any people' resistances for the injustice committed by central government are responded in military way. Third, if the conflict is resolved in Islamic way then each party should be able to understand the wisdoms of the conflict so that mazmumah can be eliminated, facing the conflict with al-karimah moral, mesyuarah and muzakarah. Return them to Allah and His Messenger, and do not take any revenge.

\section{REFERENCES}

Al-Qur`an Al-Karim.

Abu Jihad (2000), Pemikiran-Pemikiran Politik Hasan Tiro, Jakarta: Titian Ilmu insani.

Abdul Jawad (2007), Penelitian Aceh Pasca MoU Dari Persfektif Komunikasi, Jakarta: Balidbang.

Ibnu Manzur (1978), Lisan al-Arab, Mesir: Dar al-Misriyah.

Al-Chaidar (1988), Aceh Bersimbah Darah, Jakarta: Pustaka Al-Kautsar. --(1999), Gerakan Aceh Merdeka, Jakrta: Pustaka Al-Kautsar.

A. Kadir Soyb (2004), Dinamika Konflik Dalam Transmisi Demokrasi, Jakrta: LKNN Antara. 
Ahmad Tafsir (2005), Ilmu Pendidikan Dalam Persfektif Islam, Bandung: Remaja Rosdakarya.

Aisyah Abd. Rahman (1966), Al-Maqal fi Al-Insan Dirasah Qur`aniyah, Mesir: Dar Al-Maarif.

Al- Qusyairi (tt), Ar-Risalah al-Qusyairiyah, Kairo: Dar al-Kutub al Arabiyah.

A. Hasyimi (1969), Sejarah Dan Tamadun Islam, Banda Aceh: IAIN Ar-Raniry. (1995), 50 Tahun Aceh Membangun, Banda Aceh: MUI Aceh.

Ali K (2000), Sejarah Islam, Jakrta: Srigunting Raja Grafindo.

Arifianto (2004), Konflik Sosial Dan Pengelolaan Informasi, Jurnal Penelitian Komunikasi, Jakarta: LIN.

Baihaqi AK (2008), Langkah-langkah Perjuangan, Bandung: Tetungi Pasir Mendale.

Dadang Hawari (1997), Doa Dzikir Sebagai Pelengkap Terapi Medis, Jakarta: Dana Bhakti Prima Yasa.

J. Anto (2005), Resolusi Konflik Melalui Jurnalisme Damai, Jakarta: LKBN Antara

M. Nur El-Ibrahimy (1986), Tengku Muhammad Daud Berurueh, Jakarta: Gunung Agung.

Harun Yahya (1999), Negeri-Negeri Yang Telah Dimusnahkan, http//ww harun yahya.com.

Ibrahim Basuni (1969), Nasaah at-Tasawuf al- Islam, Kairo: Dar al-Maarif Bahkti Primayasa.

Ibnu Sulaiman (1995), Jin, Iblis dan Setan, Jakarta: Arista.

Ibnu Manzur (1978), Lisan al-Arab, Mesir: Dar al-Misriyah

Imam Al-Ghazali (tt), Ihya Ulum ad-Din, Beirut: Singapura-Jeddha-Indonesia Al Haramain.

Jeneral Soekanto, Serambi Indonesia No.6.990 7 Oktober 2008.

Masri A. Muchsin (2007), Potret Aceh Dalam Bingkai Sejarah, Banda Aceh: Ar-Raniry Press.

Muhammad Ali Ash-Shabuniy (1981), Shafwah At-Tafsir,Beirut: Dar Al-Qur`an Al-Karim.

Muhammad Syukri Salleh (1998), Pengurusan Krisis Secara Islam, Kertas Kerja Majlis Pengajian PPI USM Penang.

Dunia Alam Melayu

Selengor Malaysia.

Muhammad Rusli Malik (2003), Puasa Menyelami Kecerdasan Intelektual, Kecerdasan Spritual dan

Kecerdasan Emosional Di Dalam

Puasa, Jakarta: Pustaka Zahra.

Mustafa Zahri (tt), Kunci Memahami Ilmu Tasawuf, Surabaya: Bina Ilmu.

Muhammad Said (1990), Aceh Sepanjang Abad, Medan: Waspada.

M. Quraisy Shihab (1996), Wawasan Al-Qur'an, Bandung: Mizan.

Prabudi Said (2006), Berita Peristiwa 60 Tahun Wspada, Medan: Prakarsa Abadi Press.

Sugeng Satrya Dharma (2006), Aceh Lon, Damai Aceh Merdeka Abadi, Banda Aceh:

BRR Kelembagaan Kominfo.

Thoha Husein (1973), Al-Mustaqbal as- Shaqafah fi Mishr, Beirut: Dar al-Kitab Al-

Lubany.

Warul Walidi (2006), Peranan Ulama Dalam Pelaksanaan Syariat Islam di Provinsi Nanggroe Aceh

Darussalam, Banda Aceh: Cahaya

Ilmu.

Jeneral Soekanto, Serambi Indonesia No.6.990 7 Oktober 2008. 